\title{
Major Cause of Organ and Carcass Condemnation and Its Financial Loss at Bishoftu Elfora Export Abattoir
}

\author{
Aynalem Mandefro", Kassaye Aragaw ${ }^{2}$, Birhanu Hailu ${ }^{1, ~ *, ~ G e z a h e g n ~ A l e m a y e h u ~}{ }^{1}$, Gemechu Chala ${ }^{2}$ \\ ${ }^{1}$ College of Veterinary Medicine, Samara University, Samara, Ethiopia \\ ${ }^{2}$ School of Veterianry Medicine, Hawassa University, Hawassa, Ethiopia
}

Email address:

birhailu2002@gmail.com (B. Hailu)

\section{To cite this article:}

Aynalem Mandefro, Kassaye Aragaw, Birhanu Hailu, Gezahegn Alemayehu, Gemechu Chala. Major Cause of Organ and Carcass Condemnation and Its Financial Loss at Bishoftu Elfora Export Abattoir. International Journal of Nutrition and Food Sciences. Vol. 4, No. 3, 2015, pp. 364-372. doi: 10.11648/j.ijnfs.20150403.24

\begin{abstract}
The study was conducted from October 2013 to April 2014 in ELFORA export abattoir. The aim of this study was to identify and determine the major causes of organ and carcass condemnation and to estimate financial losses attributed to the condemned organs and carcasses from sheep and goats slaughtered in the abattoir. Standard antemortem and postmortem inspection procedures were followed throughout the study. Antemortem inspection was carried out in the lairage. There were higher record of nasal discharge, coughing, depression and lameness in both species. Postmortem examinations were conducted through their identification number to detect gross abnormalities and aesthetic reasons that rendered each organ to be rejected from the view of local and international markets. A total of 384 sheep and 384 goats slaughtered in the abattoir were included in the study. From these slaughtered animals, 768 organs and carcasses were examined. The study revealed that a total of $325(42.3 \%)$ livers, $285(37 \%)$ lungs, $40(5.20 \%)$ hearts, $76(9.90 \%)$ kidneys and $42(5.46 \%)$ carcasses were rejected due to various causes. Stelesia hepatica $(38.3 \%)$, pneumonia $(60 \%)$, pericarditis $(54.3 \%)$ and nephritis $(35.3 \%)$ were found to be the major causes responsible for rejection of respective organs and carcass. The annual loss due to the rejection of organs and carcasses from the small ruminants slaughtered in ELFORA export abattoir is estimated to be 79,894.58 USD. In conclusions results of the present study justify immediate need of prevention of various pathogens that causes organ and carcass condemnation and pathological abnormalities through development of animal health delivery, enforcement of slaughter policy, education on animal welfare/humane slaughter, and training of slaughterhouse personnel on standard slaughter operations.
\end{abstract}

Keywords: Sheep, Goats, Organ, Carcass, Condemnation, Export Abattoir, Antemortem Inspection, Postmortem Examination, Financial Loss

\section{Introduction}

Small ruminants are important domestic animals in the tropical animal production system (Devendra and Meclorey, 1990). Within African society, small ruminant comprise a greater proportion of the total wealth of the poor families, because of the low input requirements such as small initial capital, fewer resources and maintenance cost. They are also able to produce milk and meat in readily usable quantities using marginal lands and poor pasture and crop residues. Furthermore, their production cycle make them need only short periods to reconstitute flocks after disaster and respond quickly to the demand (Getenby, 1991).

Sheep and goat population in Ethiopia is approximately
25.98 and 21.96 million, respectively (FAO, 2010) which cover over $30 \%$ of all domestic meat production of the country. Small ruminants are found mainly in the lowland agro-ecology which constitutes $65 \%$ of the area, where $25 \%$ sheep and close to $100 \%$ goat's population exist (PACEEthiopia, 2003). They generate cash income from export of meat, edible organs, skins and live animals (Ibrahim, 1998). An increase in small ruminants production could contribute to the attainment of food self sufficiency in the country particularly in response to protein requirement for the growing human population as well as to enhance the export earnings (Teferi, 2000). 
Abattoir data is an excellent option for detecting diseases of both economic and public health importance (Arbabi and Hooshyr, 2006; Abbuna et al., 2010) especially in ascertaining the extent to which human is exposed to certain zoonotic diseases in addition to estimating the financial implications of carcass condemnations (Jobre et al., 1996). Surveillance at the abattoir allows for all animals passing in to human food chain to be examined for unusual signs, lesions or specific disease (Alton et al., 2010). Monitoring all conditions at slaughter has been recognized as one way of assessing the disease status of herd, however this source of information is not fully exploited worldwide (Mellau et al., 2010).

The purpose of meat inspection is to protect public health and to provide risk free products to the society. Also, it provides information that can be utilized for animal diseases control (Gracey et al., 1999).Meat inspection, comprising of ante mortem and postmortem examination, to remove gross abnormalities from meat and its products, prevention of distribution of contaminated meat that could result to disease risk in man and animals and assisting in detecting and eradication of certain diseases of livestock (Van Longtestijin, 1993). Ante mortem inspection attempts to avoid introduction of clinically diseased animals in to slaughterhouse and also serves to obtain information that will be useful in making sound post mortem inspection (Herenda et al., 1994; Teka, 1997).

Post mortem inspection is the centre around which meat hygiene revolves since it provides information essential for evaluation of clinical signs and pathological process that affect the wholesomeness of meat (Herenda et al., 1994). As meat is the main source of protein to man, it should be clean and free from diseases of particular importance to the public such as tuberculosis and cysticercosis. Meat is also condemned at slaughter to break the chain of some zoonoses which are not transmitted to man directly via meat like hydatidosis and other important diseases of animals such as fasciolosis (Jibat, 2006).

Each year a significant economic loss results from mortality, poor weight gain, condemnation of edible organs and carcasses at slaughter. This production loss in the livestock industry is estimated at more than 900 million USD annually (Jacob, 1979; Abebe, 1995; Jobre et al., 1996). The major causes of organs condemnation during postmortem inspection are disease caused by parasites, bacterial and other abnormalities. The final judgment as to action to be taken with an organ, carcass or part of carcass is based on the total evidence produced by the visual observation, palpation and incision (Teka, 1997).

It is necessary to have clear information on major causes of organs and carcass condemnation at the abattoir. This is important in providing information on where and how to reduce the losses that may be caused by the various abnormalities (lesions/pathology). Various studies (Jembere, 2002; Yimam, 2003; Aseffa, 2005; Getachew, 2008; Regessa et al., 2013) were carried out in the country in this regard to know the causes and economic losses associated.
However there is little information regarding to cause and associated economic loss in Bishoftu ELFORA export abattoir. Therefore, this study was designed to identify the major causes of organs and carcasses condemnation at Bishoftu ELFORA export abattoir and to assess the magnitude of direct financial losses.

\section{Materials and Methods}

\subsection{Study Area Description}

The study was conducted from October 2013 to April 2014 in ELFORA export abattoir. ELFORA abattoir is found in Bishoftu town, which is located at $90^{\circ} \mathrm{N}$ and 400 $\mathrm{E}^{0}$ with an altitude of 1880 masl in the central highlands of Ethiopia $47 \mathrm{Kms}$ South East of Addis Ababa. It has annual rainfall of $1151.6 \mathrm{~mm}$ of which $84 \%$ falls down during the long rainy season that extends from June to September and the remaining during the short rainy season that extends from March to May. The mean annual minimum and maximum temperatures is $8.5^{\circ} \mathrm{C}$ and $30^{\circ} \mathrm{C}$, respectively, and the mean humidity is $61.3 \%$ (NMSA, 2003). The study animals were small ruminants destined for slaughter. These animals were all males originated from different parts of the country including Arsi, Bale, Afar, Shewa, Wollo, Omo, Borena and Jenka. They were transported to the abattoir using vehicles.

\subsection{Study Design and Methodology}

A cross-sectional study was conducted in sheep and goats slaughtered in ELFORA abattoirs with the study period ranged from October 2013 to April 2014 in the export abattoir to identify the major cause of organ and carcass condemnation. In this study, animals were grouped in to young (under 1 year of age in goats and 1years and 3 months in sheep) based on eruption of one or more incisor teeth according to (Vatta et al., 2005). Animals belonging to a group of young and adult were randomly sampled using systematic sampling method and examined by ante mortem and postmortem examination. Sample size was calculated using the formula given by (Thrusfield, 2005) with 50\% expected prevalence, 95\% confidence interval and 5\% desired absolute precision. Accordingly, the sample size was determined to be 384 for each species.

\subsection{Abattoir Survey}

\subsubsection{Antemortem Inspection}

In the cross-sectional study of active abattoir survey, both ante mortem and post mortem inspections were carried out in accordance with the procedures of Ethiopian Ministry of Agriculture Meat Inspection Regulation (EMAMIR, 1972). In the ante mortem inspection, pre-slaughter examinations of small ruminants were conducted at lairage and various information concerning age; body condition score and origin of each study animals were properly recorded. The age grouping was done based on dentition standard given by Vatta et al., 2005). Those animals which have not 
erupted permanent incisor teeth and one pair of permanent incisors (i.e. $<1$ year to $1 \frac{1 / 2}{2}$ years (for sheep) and $<1$ year to 2 years (for goats)) were grouped as young. Those having two pairs and above permanent teeth (i.e. $\geq 1 \frac{1}{2}$ years (for sheep) and $\geq 2$ years (for goats) were grouped as adult. Body condition scoring was carried out based on the handbook given by Ethiopian Sheep and Goat Productivity Improvement Program (ESGPIP, 2008). The scores were classified in to six categories namely starving $(0)$, very thin (1), thin (2), moderate (3), fat (4) and very fat (5). For convenience, these categories were summarized in to three classes as poor ( 0 and 1), medium (2 and 3 ) and good (4 and 5). Additionally, general behavior of the animals nutritional status, cleanliness and sign of diseases and abnormality of any type were registered according to the standard ante mortem inspection procedures and animals that were fit for human consumption were allowed for slaughter (Gracey, 1986).

\subsubsection{Post Mortem Examination}

During postmortem inspection liver, lungs, heart, kidney, brain and carcasses were thoroughly inspected by visualization, palpation and making systemic incisions where necessary for the presence of cysts, parasites and other abnormalities. Pathological lesions were differentiated and judged according to guidelines on meat inspection for developing countries (Herenda et al., 1994). The results were recorded and the decisions were classified as totally approved, partially approved, conditionally approved as fit for human consumption and totally condemned as unfit for human consumption (FAO, 1993).

\subsection{Assessment of Financial Loss}

All affected organs and carcasses were rejected from international market since partial approval was not practiced in the abattoirs and the analysis was based on the annual slaughter capacity of the abattoirs considering market demand, average market prices in international and local market and the rejection rates of specific organ and carcass. The annual slaughter rates were estimated from retrospective abattoir record. The economic loss due to condemnation was estimated by the formula set by Ogunrinade (Ogunrinade, 1980). As follows:

$$
E L=\sum \operatorname{srx} \cdot \operatorname{Coy} \cdot \operatorname{Roz}
$$

where: $E L=$ Annual financial loss estimated due to organ and carcass condemnation from

International market. $\Sigma$ srk = Annual sheep/ goats slaughter rate of the abattoir

Coy $=$ Average cost of each sheep or goats liver/ lung/ heart/ kidney/ brain and carcass
Roz $=$ Condemnation rates of

sheep/goats/liver/lung/heart/kidney/brain and carcass

\subsection{Data Analysis}

Collected data from records and from active abattoir survey were entered in to Excel spread sheet and process of coding, cleaning and validating was done on this sheet. For the data from post mortem inspection, descriptive statistics were used to determine organ and carcass condemnation rates, defined as proportion of organs and carcasses condemned to the total number of organs and carcasses examined. The respective financial losses were also calculated. Possible variation between rejection rates of specific organs, age groups and species were taken into consideration.

\section{Result}

\subsection{Abattoir Survey}

\subsubsection{Antemortem Inspection}

Antemortem inspection was carried out on all 768 shoats (384 ovine and 384 Caprine) for the detection of any abnormalities encountered in the ELFORA export slaughter houses. A total of $82(21.35 \%)$ caprine and $81(21.09 \%)$ ovine species were found to have abnormalities listed bellow (Table 1). Nasal discharge, coughing, depression and lameness were frequently observed in both species.

Table 1. Summary of abnormalities or condition encountered during antemortem inspection in both species.

\begin{tabular}{llll}
\hline $\begin{array}{l}\text { Abnormality/condition } \\
\text { encountered }\end{array}$ & $\begin{array}{l}\text { Caprine } \\
(\mathbf{n = 3 8 4 )} \%\end{array}$ & $\begin{array}{l}\text { Ovine } \\
(\mathbf{n = 3 8 4}) \%\end{array}$ & $\begin{array}{l}\text { Total } \\
(\mathbf{n = 7 6 8}) \%\end{array}$ \\
\hline Nasal discharge & $34(8.85)$ & $37(9.64)$ & $71(9.3)$ \\
\hline Depression & $15(3.9)$ & $0(0)$ & $15(2)$ \\
\hline Coughing & $17(4.43)$ & $15(3.91)$ & $32(4.1)$ \\
\hline Local swelling & $2(0.52)$ & $3(0.78)$ & $5(0.65)$ \\
\hline Emaciation & $3(0.78)$ & $9(2.34)$ & $12(1.56)$ \\
\hline Lameness & $11(2.86)$ & $17(4.43)$ & $28(3.64)$ \\
\hline Total & $82(21.35)$ & $81(21.09)$ & $163(21.2)$ \\
\hline
\end{tabular}

\subsubsection{Postmortem Examination}

All animals that had been examined by antemortem inspection were also subjected to postmortem examination. A total of 768 shoats (384 ovine and 384 caprine) were slaughtered and thoroughly examined by following standard postmortem procedure. From the total organs examined in both species 325 (42.3\%) livers, 285 (37.4\%) lungs, $40(5.20 \%)$ heart, 76(9.90\%) kidney, 42 (5.46\%) carcass were condemned from the international and local market based on their gross pathological lesions as shown in table 2 . 
Table 2. Total number of animal slaughtered and rejection rate of specific organs.

\begin{tabular}{|c|c|c|c|c|c|c|}
\hline \multirow{2}{*}{$\begin{array}{l}\text { Animal Species } \\
\text { Ovine }\end{array}$} & \multicolumn{5}{|c|}{ Organ and carcass condemnation $\mathbf{n}(\%)$} & \multirow[t]{2}{*}{ Total examined organs } \\
\hline & Liver & Lung & Heart & Kidney & Carcass & \\
\hline Young & $76(46.5)$ & $71(37.2)$ & $10(5.2)$ & $13(7.9)$ & $9(5.2)$ & 179 \\
\hline Adult & $98(60.1)$ & $61(34.7)$ & $12(7.3)$ & $23(13.5)$ & $11(7.3)$ & 205 \\
\hline Sub-total & $174(53.3)$ & $132(36)$ & $22(6.52)$ & $36(10.68)$ & $20(6.25)$ & 384 \\
\hline Caprine & Liver & Lung & Heart & Kidney & Carcass & \\
\hline Young & $66(37.1)$ & $71(38.7)$ & $8(4.2)$ & $20(11.0)$ & $9(5.2)$ & 174 \\
\hline Adult & $85(46.1)$ & $82(43.0)$ & $10(7.3)$ & $20(10.4)$ & $13(6.7)$ & 210 \\
\hline Sub-total & $151(41.3)$ & $153(40.8)$ & $18(5.72)$ & $40(10.68)$ & $22(5.98)$ & 384 \\
\hline Grand total & $325(42.30)$ & $285(37)$ & $40(5.20)$ & $76(9.90)$ & $42(5.46)$ & 768 \\
\hline
\end{tabular}

The frequency of liver condemnation was higher in sheep $(205 / 384,53.3 \%)$ than in goats $(160 / 384,41.6 \%)$ with statistical significance variation $(\mathrm{P}=0.014)$. However, there was no observed statistical difference in condemnation rates for lungs, hearts, kidneys and carcasses between the two species and age groups ( $>00.05)$. Parasites of $S$. hepatica, Fasciola species, Cysticercus tenuicollis and hydatid cysts were major causes of livers condemnation with rates of $140 / 365(38.3 \%), 20(5.47 \%), 53(14.3 \%)$ and $9(2.45 \%)$ respectively. Hepatitis at a rate of $101(27.6 \%)$, abscess
$11(3 \%)$ and calcification $45(12.3 \%)$ found to be significant causes of liver condemnation. Fasciolosis caused higher liver condemnations in sheep $(3.92 \%)$ than in goats $(1.3 \%)$ and hepatitis was found to be a major cause of liver condemnation in sheep $(21.8 \%)$ than in goats $(4.69 \%)$. However, $S$. hepatica caused higher rate of liver condemnation in goats $(12.1 \%)$ than in sheep $(9.5 \%)(p=$ 0.043). Similarly, Cysticercus tenuicollis cause significant losses in goats $(8.07 \%)$ than in sheep $(5.73 \%)$ and all these results were indicated in table 3.

Table 3. Summary liver condemnation and rejection rate in both species.

\begin{tabular}{|c|c|c|c|c|c|c|}
\hline \multirow[b]{3}{*}{ Abnormalities } & \multicolumn{6}{|c|}{ Percentage and frequency of liver condemnation } \\
\hline & \multicolumn{3}{|l|}{ Ovine (n\%) } & \multicolumn{3}{|c|}{ Caprine (n\%) } \\
\hline & Young & Adult & Total & Young & Adult & Total \\
\hline Hepatitis & $39(20.4)$ & $44(22.8)$ & $83(21.61)$ & $7(3.7)$ & $11(5.7)$ & $18(4.69)$ \\
\hline Stelesia hepatica & $18(9.4)$ & $31(16.1)$ & $49(12.76)$ & $42(22.0)$ & $49(25.4)$ & $91(23.7)$ \\
\hline C. tenuicolis & $10(5.2)$ & $12(6.2)$ & $22(5.73)$ & $7(3.7)$ & $10(5.2)$ & $31(8.07)$ \\
\hline Calcification & $10(5.2)$ & $16(8.3)$ & $26(6.77)$ & $10(5.2)$ & $9(4.7)$ & $19(4.95)$ \\
\hline Hydatidosis & $4(2.1)$ & $1(0.5)$ & $5(1.30)$ & $1(0.5)$ & $3(1.6)$ & $4(1.04)$ \\
\hline Abscess & $1(0.5)$ & $4(2.1)$ & $5(1.30)$ & $2(1.0)$ & $4(2.1)$ & $6(1.56)$ \\
\hline Fasciolosis & $7(3.7)$ & $8(4.1)$ & $15(3.91)$ & $2(1.0)$ & $3(1.6)$ & $5(1.30)$ \\
\hline Total & $89(46.59)$ & $116(60)$ & $205(53.38)$ & $71(37.1)$ & $89(46.1)$ & $160(45.3)$ \\
\hline
\end{tabular}

A total of $138(35.9 \%)$ and 157(50.9\%) lungs were condemned in sheep and goats respectively. The major causes of lung condemnation were by pneumonia comprising $60 \%$ followed by emphysema $17 \%$. There was no statistically significance difference $(\mathrm{p}>0.05)$ for all causes of lung condemnation between age and species of sheep and goat. Rate of condemnations due to hydatidosis was higher in the lungs $2.08 \%$ in sheep than $0.78 \%$ in goats as shown in Table 4.

Table 4. Summary of lung condemnation and rejection rate in both species.

\begin{tabular}{|c|c|c|c|c|c|c|}
\hline & \multicolumn{6}{|c|}{ Percentage and frequency of lung condemnation ( $\mathrm{n} \%$ ) } \\
\hline & Caprine & & & Ovine & & \\
\hline Abnormalities & Young & Adult & Total & Young & Adult & Total \\
\hline Pneumonia & $48(25)$ & $48(24.9)$ & $96(25.00)$ & $46(24.1)$ & $37(19.2)$ & $83(21.01)$ \\
\hline Hydatidosis & $1(0.5)$ & $2(1.0)$ & $3(0.78)$ & $3(1.6)$ & $5(2.6)$ & $8(2.08)$ \\
\hline Calcification & $6(3.1)$ & $9(4.7)$ & $15(3.91)$ & $5(2.6)$ & $4(2.1)$ & $9(2.34)$ \\
\hline C. teniculosis & $7(3.7)$ & $10(5.2)$ & $17(4.43)$ & $6(3.1)$ & $5(2.6)$ & $11(2.86)$ \\
\hline Emphysema & $12(6.3)$ & $14(7.3)$ & $26(6.77)$ & $11(5.6)$ & $16(8.3)$ & $27(7.03)$ \\
\hline Total & $74(19.27)$ & 83 (21.6) & $157(40.88)$ & $71(37.1)$ & 67 (31.6) & $138(35.93)$ \\
\hline
\end{tabular}

Out of a total of 45 hearts condemned, pericarditis contributed $54.3 \%$ as major cause followed by calcification $(32.6 \%)$ and abscess (10.9\%). No statistically significant difference was observed between the two species and age groups $(p>0.05)$ in heart condemnation rate as listed in Table 5. 
Table 5. Summary of heart condemnation and rejection rate.

\begin{tabular}{|c|c|c|c|c|c|c|}
\hline \multirow{2}{*}{ Abnormalities } & \multicolumn{6}{|c|}{ Percentage and frequency of heart condemnation (n\%). } \\
\hline & Ovine & & & Caprine & & \\
\hline Age group & Young & Adult & Total & Young & Adult & Total \\
\hline Pericarditis & $4(2.1)$ & $7(3.6)$ & $11(2.86)$ & $5(2.6)$ & $9(4.7)$ & $14(3.65)$ \\
\hline Calcification & $3(1.6)$ & $5(2.6)$ & $8(2.08)$ & $3(1.6)$ & $4(2.1)$ & $7(1.82)$ \\
\hline Abscess & $2(1.0)$ & $2(1.0)$ & $4(1.04)$ & $0(0)$ & $1(0.5)$ & $1(0.26)$ \\
\hline Total & $9(4.7)$ & $14(7.25)$ & $23(5.98)$ & $8(2.08)$ & $14(3.64)$ & $22(5.7)$ \\
\hline
\end{tabular}

Renal problems were observed in 82 pairs $(10.6 \%)$ of the total kidneys examined. Nephritis accounting for $35.36 \%$ $(29 / 82)$ followed by calcification $31.7 \%$ (26/82) which was the major pathological lesions. There is no statistically significance association for the causes of kidney condemnation between sheep and goat and age groups $(\mathrm{p}>0.05)$ as indicated in table 6 .

Table 6. Summary of kidney condemnation and rejection rate.

\begin{tabular}{|c|c|c|c|c|c|c|}
\hline \multirow{3}{*}{ Abnormality } & \multicolumn{6}{|c|}{ Percentage and frequency of kidney condemnation (n\%) } \\
\hline & \multicolumn{3}{|l|}{ Caprine } & \multicolumn{3}{|l|}{ Ovine } \\
\hline & Young $(\mathrm{n}=191)$ & Adult $(n=193)$ & Total & Young & Adult & Total \\
\hline Abscess & $2(1.0)$ & $1(0.5)$ & $3(0.78)$ & 0 & 0 & - \\
\hline Calcification & $6(3.1)$ & $7(3.6)$ & $13(3.39)$ & $5(2.6)$ & $8(4.1)$ & $13(3.39)$ \\
\hline Mechanical damage & $4(2.1)$ & $7(3.6)$ & $11(2.86)$ & $6(3.1)$ & $7(3.6)$ & $13(3.39)$ \\
\hline Nephritis & $9(4.7)$ & $5(2.6)$ & $14(3.65)$ & $4(2.1)$ & $11(5.7)$ & $15(3.91)$ \\
\hline
\end{tabular}

The major pathological conditions for carcass rejection (15/47) followed by Adhesion $(25.53 \%$; 12/47) during this from international market were bruising accounting for $31.91 \%$ study as shown in table 7 .

Table 7. Summary of carcass condemnation and rejection rate.

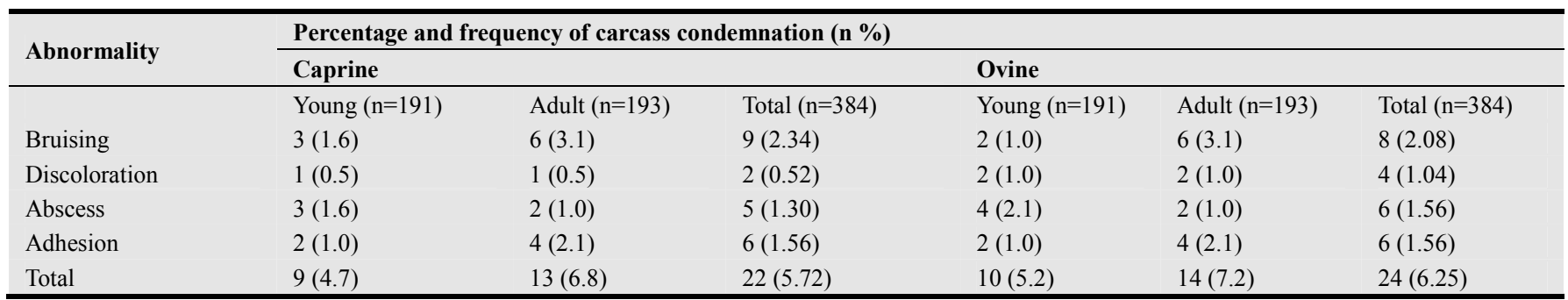

\subsection{Estimation of Financial Losses}

Estimated of annual financial loss was computed based on the annual slaughter rate of both species, average cost of condemned organ and carcass during the study period and condemnation rate of the slaughter house as indicated in the above equations. Based on these parameters, the annual financial loss was estimated to be 79894.58 USD from both domestic and international markets.

\section{Discussion}

Ante mortem and post mortem inspections were conducted in the abattoir for the purpose of screening and removing animal products with pathological lesions which were unsafe for human consumption and having poor aesthetic values. It was indicated that meat inspection assist in monitoring diseases in national herd and flock by providing feedback information to veterinary service to control or eradicate diseases and to produce wholesome products and to protect public from zoonotic hazards (Van Llogtestijn, 1993; Gracey et al., 1999). Hence, the gathered information from abattoir record can be used by farmers to improve the husbandry of their animals in such a way that farmers can improve the overall management of their animals so that pre-slaughter problems would be reduced (Edwards et al., 1999).

Meat inspection and meat hygiene shall make sure that meat and meat products are safe and wholesome for human consumption. The classical ante-mortem and post-mortem procedures were designed to detect disease in an animal before slaughter and lesions produced by the disease after slaughter respectively (Herenda et al., 2000). The most commonly encountered abnormalities during ante mortem inspection were nasal discharge, lameness, localized swelling and coughing. Diseased animals that show signs of 
abnormality during ante mortem inspection should not be allowed to enter the abattoir for slaughter (Teka, 1997).

During the ante mortem examinations, it was found that lameness and respiratory disorders were relatively the highest abnormalities encountered during the ante mortem inspection. According to the information obtained from the suppliers, most causes of lameness was trauma caused by inappropriate vehicles and loading and off-loading negligence during transportation to market places and to the abattoir a similar reason with (Regessa et al., 2013). The respiratory signs such as presence of nasal discharge, coughing, sneezing were most probably related to stress due to lack of feed and water, immune suppression and overcrowding during transportation which was in line with Getachew (2008). In the present study, organ condemnation rate showed that, liver and lung were the most frequently affected organs with the highest condemnation rate followed by kidney, heart and carcass. This finding is in agreement with reports of Cadmus and Adesokan (2009) who recorded that lungs $(45.7 \%)$ and the liver $(32.9 \%)$ were the most affected organs with the kidney $(0.02 \%)$ and the heart $(0.01 \%)$ being the least. Similar findings were also reported from Gondar, Northern Ethiopia (Yimam, 2003) and Nigeria (Ojo, 1992). Parasites and poor management practices were the major causes of organ and carcass condemnations. Losses from liver condemnation were assumed to occur since hepatic pathology is associated to infection that might have public health importance (Radostitis et al., 2000; Budke et al., 2006) and aesthetic value.

A high number of livers $(47.5 \%)$ were condemned from sheep and goat due to several reasons: from the total shoats slaughtered, parasites like Cysticercus tenuicollis, Stilesia hepatica, and fasciola species were found to be the major causes that rendered liver rejection from international market. Previous studies have indicated a higher economic loss resulting from condemnation of edible organs and carcasses due to parasitic causes (Negategize et al., 1993; Jembere, 2002; Aseffa, 2005; Jibat, 2006). The higher rate of fasciolosis observed in sheep in comparison with goats could be due to their feeding behavior where sheep are usually grazers and goats tend to be more of browsers making them less exposed to the parasite (Mungube et al., 2006).

Cumulative incidence of liver condemnation due to $S$. hepatica at $9.1 \%$ and $12.5 \%$ in sheep and goats, respectively, which is similar report was observed (Ejeta et al., 2008). The epidemiology of S. hepatica and C. tenuicolis was not well established in sheep and goats; hence, it may be difficult to explain why significantly more livers were condemned in goats than in sheep.

Lungs were condemned from the total lungs inspected in $35 \%$ ovine and $40 \%$ caprine species from being used as pet food because of reasons like pneumonia, emphysema, hydatid cysts and cysticercus tenuicolis. Pneumonia accounts for $60 \%$ as a principal cause of lung condemnation both in sheep and goat. Similar report was observed during retrospective study (Regassa et al., 2013). It was also reported pneumonia as a principal cause of lung condemnation in central Ethiopia accounting for $42.1 \%$
(Getachew, 2008). It is observed that animals transported on foot suffer from transportation stress and lack of feed and water route. Those which were transported on open trucks are overcrowded and furthermore, animals are suffocated at the lairages and there was short resting time before slaughter for the animals to recover from physical stresses. These conditions were causes of pneumonia and emphysema as observed at a higher magnitude in this study. This indicates also violation of animal welfare stretching from farm to slaughter. Pneumonia might be also as a result of endemic diseases of sheep and goats such as pasteurellosis, which is triggered by stress, contagious caprinepleuro pneumonia (Radiostitis et al., 2007).

Furthermore, different lesions of infectious and noninfectious causes like abscess, pericarditis, nephritis, and jaundice were found to be important causes for the condemnation of edible organs like liver, heart, and kidney. Similarly the same causes were found at central Ethiopia (Getachew, 2008; Regassa et al., 2013) and in goats slaughtered at Nigeria (Ojo, 1992). Bruising was observed as major cause of carcass condemnation which is $36 \%$. Bruising occurs due to beating of animals during transportation and the use of rough vehicles. Apart from affecting carcass value, bruising has also animal welfare implications as excessive use of sticks while driving to the abattoir, mishandling of animals during loading and unloading, improper transport vehicle and at slaughter could be responsible causes (Edward et al., 1997). It is stated that bruising of animals during transport is the major source of economic loss in Africa and Asia (Mitchell and slough, 1980). Though the abattoir does not export partially approved organ and carcass, loss due to bruising is more apparent in partially and totally condemned carcasses (Gracey et al., 1999).

The direct financial loss in this abattoir was relatively higher because of its export standard. However, this study analyzed those losses only through condemnation of edible organs and carcasses from international market during the study period. A total annual financial loss of 79894.58 USD was observed due to export organs and carcasses condemnation from the 768 inspected sheep and goats. Still, some of the rejected carcasses which were unfit for international market were sold with relatively lower price (half price) to the domestic market as a fit product for consumption since no risk of public health was recorded in them. Similarly, approved lungs were sold at local market. In general, as the main objective of the abattoir is to export meat and only a few items with minor defects and poor nutrition status (in case of carcass) were sold in the domestic market and the proportion of the exported items were much higher than that used for domestic consumption.

\section{Conclusion and Recommendations}

Our study revealed that from the total organs and carcasses condemned: $42.3 \%, 37 \%, 5.20 \%, 9.90 \%$ and $5.5 \%$ were liver, lung, heart, kidney and carcass respectively. It was as to parasitic diseases, other pathological conditions, mechanical 
damage during evisceration and bruising. There was high financial loss burden because of organ and carcass condemnation at ELFORA abattoir, which may also reflect the same scenario in other slaughterhouses in Ethiopia.

Based on these conclusions, the following recommendations are worth mentioning:

- Standard regulations and functional meat inspection policies should be formulated for organs and carcass approval/ rejection for abattoirs in order to have positive relation with importing countries so that profitable and sustainable international meat trade to be continued

- Immediate, safe and controlled elimination of all condemned abattoir materials and the sale of contaminated offal and heads as dog's feed should be prohibited by law

- Regular deworming of small ruminants and dogs and elimination of stray dogs should be practiced

- Training of abattoir workers on procedures and cares during flaying and evisceration should be done

- awareness should be created in producers, local and medium traders, of the animal attendants, farmers, customers and abattoir workers pertaining to and proper disposal of condemned offals' and carcasses.

- Further studies should be carried out in small ruminants that are going to be slaughtered in different abattoirs of the country and introduce preventive measures to reduce unnecessary financial losses encountered in the industry.

\section{References}

[1] Abebe, G. (1995): Current status of veterinary education and health research in Ethiopia In: Veterinary Medicine impact on health and nutrition in Africa. Proceeding of an international conference ILRI, Addis Ababa, pp: 133-138.

[2] Abbuna, F., Asfaw, L., Megersa,B. and Regassa, A. (2010): Bovine fasciolosis: Coprological, abattoir survey and its economic impact due to liver condemnation at Sodo Municipal abattoir, Southern Ethiopia. Tropical Animal Health and Production, 42: 289-292.

[3] Alton, G.D., Lpeah, D., Bateman, K.J., McNab,W.B. and Berk, O. (2010): Factors associated with whole condemnation rates in provincially inspected abattoir in Ontario 2001-2007: Implication for food animal syndromic surveillance. BMC Veterinary Research, 6: 42.

[4] Annon, A. (1990): FAO WHO guide line for surveillance, prevention and control of echinococcus/hydatidosis Surveillance World organization, Pp. 146-153.

[5] Arbabi, M. and Hooshyar, H. (2006): Survey of Echinococcosis and Hydatidosis in Kashun Region, Central Iran. Iranian J. PublicHealth, 35: 75-81.

[6] Arundel, J.H. and Radoistits, O.M. (2000): veterinary medicine: A text book of the disease of cattle, sheep, pigs. Elsevier Health Sciences.Pp.45-47.

[7] Aseffa, M., (2005): Parasitic Causes of Carcass/Organ Condemnation at Asella Municipality Abattoir. Unpublished DVM Thesis, Faculty of Veterinary Medicine, Addis Ababa University, Debrezeit, Ethiopia.
[8] Ayechew, S. (2007): Causes of Organs and Carcasses condemnation in goats slaughtered at HELMEX abattoir, Debrezeit, DVM Thesis, Faculty of Veterinary Medicine, Addis Ababa University, Debrezeit, Ethiopia. Pp. 9-11 (un published).

[9] Bekele T., Mukassa M. E., Kasali O. B.: The prevalence of cysticercosis and and hydatidosis in Ethiopian sheep. Vet. Parasitol. 28:267-270.

[10] Budke, C.M. Deplazes, P.and Torgerson, P.R. (2006). Global socio economic impacts of cystic echinococosis. Emer infec. Dis., 12: 296-302.

[11] Cadmus, S.I.B., Adesokan, H.K., (2009). Causes and implications of bovine organs/offal condemnations in some abattoirs in Western Nigeria Trop. Anim. Health Prod., http://dx.doi.org/ 10.1007/s11250-009-9334-7.

[12] Devendra, C. and Meclorey, G. (1990). Goat and sheep production in the tropics. Singapore, Longmont. Pp.1-5.

[13] Ethiopian Ministry of Agriculture Meat Inspection Regulations (1972). Legal Notice No. 428 Negarite Gazexa. Addis Ababa, Ethiopia.

[14] ESGPIP (Ethiopian Sheep and Goat Productivity Improvement Program), 2008. Sheep and Goat Production Handbook for Ethiopia.

[15] Edwards, D.S., A.M. Johnston and G.C. Mead, 1997. Meat inspection and overview of present practice and future trends. Vet. J., 115544: 135-147.

[16] Edward, D., S,Christiansen, K.H., Johnston ,A.M. and Mead, G.C (1999): Determination of farm level risk factors for abnormalities observed during postmortem meat inspection.

[17] Ejeta ,G., Jibat,T., Asfaw,Y. and Wudie,A.(2008): Causes of abattoir condemnation in apparently healthy slaughtered sheep and goats at HELMEX abattoir, Debre Zeit, Ethiopia Revue Méd. Vét. 5: 305-311.

[18] FAO, 1993. Agro State Data. Statistical Division, www.fao.org/economic/ess publications/ ess-yearbook/en/ Rome, Italy.

[19] FAO, 2010. FAO Statistical Year Book. Statistics Division, www.fao.org/economic/ess yearbook/en/Rome,Italy.

publications/ess-

[20] Fromsa, A. and Jobre, Y. (2011): infection prevalence of hydatidosis (Echinococcus granulosus, Batsch, 1786) in domestic animals in Ethiopia: A synthesis report of previous surveys, Ethiopia Vet. J., 15(2):11-33.

[21] Gatenby, R. M. (1991). Sheep: The tropical agriculturalist. London and Basingstoke, MACMILLAN education Ltd, ACCT. pp. 6-10.

[22] Getachew, E.W (2008). Major Diseases of Export Oriented Livestock in Export Abattoirs in/Around Ada Liben Woreda, Debrezeit. Online DVM Thesis, Faculty of Veterinary Medicine, Haramaya University, Ethiopia.http://mahider.ilri.org/handle/10568/695.

[23] Getaw, A., Beyene, D., Megersa, B. and Abunna, F. (2010): Hydatidosis: Prevalence and its economic importance in ruminants slaughtered at Adama municipal abattoir, central Oromia, Ethiopia. ActaTropica, 113: 221-225. 
[24] Gracey, J.F (1986). Meat Hygiene, 8th ed. Baillere Tindall, London, Philadelphia, Toronto, pp. 239-289.

[25] Gracey, J.F., Collins, D.S. and Huey, R.J. (1999): Meat hygiene. 10th Edition, London. W. B. Sounders Company Ltd. pp: 758 .

[26] Herenda, D., Chambers, P.G., Ettriqui, A., Seneviratnap, P., DaSilvat, T.J.P., (1994). Manual on Meat Inspection for Developing Countries. Food and Agricultural Organization of the United Nations (FAO), Rome,Italy.

[27] Herenda, D., P.G. Chambers, A. Ettriqui, P. Seneviratna and T.J.P. da Silva. (2000). FAO Animal Production and Health, Manual on Meat Inspection for Developing Countries, Food and Agriculture Organization of the United Nations, Rome.

[28] Ibrahim, H. (1998): Small Ruminant Production Techniques. ILRI Manual3. ILRI (International Livestock Research Institute), Nairobi, Kenya, 207pp.

[29] Jacob, L. (1979): Seminar for animal health officials. Ministry of agriculture and settlement, Animals and Fisheries authority. Addis Ababa, Ethiopia.

[30] Jembere, S (2002): A Survey of Causes of Organs/Carcass Condemnation in Slaughtered Cattle at Nazareth Abattoir. Unpublished DVM Thesis, Faculty of Veterinary Medicine, Addis Ababa University, Debre Zeit.

[31] Jibat, T (2006): Causes of Organ and Carcass Condemnation in small ruminants slaughtered at HELMEX Abattoir. DVM Thesis, Faculty of Veterinary Medicine, Addis Ababa University, Debrezeit, Ethiopia, pp. 9-11.

[32] Jobre, Y., Lobago, F., Tiruneh, R., Abebe, G and Dorchies, P.H (1996):Hydatidosis in three selected regions of Ethiopia: An assessment trial on the prevalence, economic and public health importance. Revue de medicine. Veterinaire, 147: 797-804.

[33] Johns, T.C., Hunt, R.D and King, N.W (1996): Veterinary pathology 6th edition. Lipincott, Williams and Wilkins, USA.Pp.966-1099.

[34] Kassai, T. (1999): Veterinary Helminthology. Butter worthHelmsmann, U.S.A. Pp. 4-47.

[35] Kaufmann, J. (1996): Parasitic infections of domestic animals, a diagnostic manual Brikhouseverlog, Based Boston, Berlin. Pp.280-283

[36] Kebede, N., Tilahun, A. G. and Wossene, A. (2009): Financial loss estimation, prevalence and characterization of hydatidosis of cattle slaughtered at DebreMarkoss municipality abattoir, Ethiopia. Tropical Animal Health and Production, 41:17871789.

[37] Khan, C. M. (2005): the Merck Veterinary Manual. 9th ed. Merial Limited, U.S.A. Pp. 1188-1189.

[38] Malone, J. B., Gommes, R., Hansen, J., Yilma, J. M., Slingeberg, J., Snijders, F., Nachet, O. F. and Ataman, E. (1998): A geographic information system on the potential distribution and abundance of Fasciola hepatica and Fasciola gigantic in East Africa based on food and agriculture organization databases. Veterinary Parasitology, 78: 87-101.

[39] Mellau, L.S.B., Longa, H.E. and Karimuribu, E.D. (2010): A Slaughter house survey of liver lesion in slaughter cattle, sheep and goats at Arusha .Tanzanian Veterinary Journal, 3: 179-188.
[40] Mezegebu, Y. (2003): Major cause of organ condemnation in ruminants slaughtered at Gonder Abattoir, North Western Ethiopia. DVM thesis,Faculty of Veterinary Medicine, Addis Ababa University, Debre-Zeit, Ethiopia.

[41] Mitchell, J. R. and Slough, C.A.B (1980). Guide to meat inspection in tropics: Common Wealth Agricultural Burro.

[42] Mungube E. O., Bauni S. M., Tenhagen B. A, Wamae L. W., Nginyi J. M., Mugambi J. M. (2006) The prevalence and economic significance of Fasciola gigantica and Stilesia hepatica in slaughtered animals in the semi-arid coastal Kenya. Trop. Anim. Hlth. Prod., 38: 475-483.

[43] Negategize, P.K.J., Bekele, T., Tilahun, G., 1993. Financial losses caused by ovine fasciolosis in the Ethiopian highlands. Trop. Anim. Health Prod.25, 155-161.

[44] NMSA (2003): National Meteorology Service Agency. Addis Ababa, Ethiopia.

[45] Oglesbee, B. L. (2011): Black well's five-minute veterinary consult: small mammal. Pp.226.

[46] Ogunrinade, A. and Ogunrinade, B.I. (1980): Economic importance of bovine fasiolosis in Nigeria. Trop. Anim. Hlth. Prod.12:155-160.

[47] Ojo, S., 1992. A Survey of Pathological Conditions in the Slaughter Goats in Zaria Slaughterhouse. Faculty of Veterinary Medicine, Ahmadu Bello University, Zaria, pp. 1-4.

[48] PACE-Ethiopia. (2003): Experiences and the way forward on community based animal health service delivery in Ethiopia. Proceedings of a workshop held in Addis Ababa Ethiopia. p.6.

[49] Radostitis, O.M, Gay, C.C., Hincheliff, K.W. (2000): Veterinary Medicine. A text book of the disease of cattle, horse, sheep, pigs, and goats.9ed ed. London: Ballier Tindals. .Pp.1378-1383.

[50] Radostitis, O.M, Gay, C.C., Hincheliff, K.W. and Constable, P.D. (2007): Veterinary Medicine. A text book of the disease of cattle, horse, sheep, pigs, and goats.10ed ed. London: Ballier Tindals. .Pp 391-517.

[51] Regassa, A., Moje, N., Megersaa , B., Beyene, D., Sheferaw, D., Debela, D., Abunnaa, F., Skjerved, E (2013): Major causes of organs and carcass condemnation in small ruminants slaughtered at Luna Export Abattoir, Oromia Regional State, Ethiopia. Preventive Veterinary Medicine 110: 139- 148.

[52] Robert, J.A. and Suhurdono, S. (1996): Approaches to the control of fasciolosis in ruminants. International journal for parasitology. 26:971-981.

[53] Schwantz, P.M. (1990): Parasitic zoonosis in perspective. International journal parasitol. 21(20):165-166.

[54] Sexena, C. B., Ral, P. and Shriva, V. P. (2008): veterinary post mortem inspection. Alaboratory manual. 1st ed. New Delhi, vikas.Pp.52-72.

[55] Teferi, M (2000): An epidemiological study on ovine pasturelosis in Arsi, south east Ethiopia Debre Zeit: Faculty of Veterinary Medicine, Addis Ababa University, DVM Thesis.

[56] Teka, G. (1997): Meat hygiene. In: Food hygiene principles and methods of food born disease control with special reference to Ethiopia, pp: 99-113. 
[57] Thrusfieled,M.(2007): veterinary Epidemology, 3rd ed.Blackwell Science, London. Pp260 265.

[58] Urquhart, G.M., Duncan, J., Armour, L., Dunn, J. and Jenning, A.M. (1996): Veterinary parasitology. 2nd Edition, Blackwell Science, Oxford, 120-129.

[59] Vanlontestijn, J.G. (1993): Integrated quality. Meat safety: A new approach. Meats Focus International, 2:123-128.

[60] Vatta, A.F., Gumede, S.A., Harrison, L.J.S., Krecek, R.C., Letty, B.A., Mapeyi, N., Pearson, R.A.(2005): Goatkeepers' Veterinary Manual. Onderstepoort Veterinary Institute, Private Bag Onderstepoort, South Africa.
[61] Vegad, T. L. (1995): A text Book of Veterinary general Phathology. Bharat, Vikas Pp. 122- 156.

[62] WHO (1984): The relationship of tropical disease and HIV infection: report on informal consultation held at Kenya Medical Research Institute (KEMRI).57: 12-13.

[63] Yimam, M. (2003): Major Causes of Organ Condemnation in Ruminants Slaughtered at Gondar Abattoir, North West Ethiopia. Unpublished DVM Thesis, Faculty of Veterinary Medicine, Addis Ababa University, Debrezeit. 